\title{
PERIODICAL MEASUREMENTS OF VLF RADIO SIGNALS AND NOISE SOUNDS IN ČRNA JAMA (POSTOJNSKA JAMA)
}

\author{
OBČASNE MERITVE VLF RADIJSKIH SIGNALOV IN ŠUMOV \\ V ČRNI JAMI (POSTOJNSKA JAMA)
}

\author{
Igor KACHALIN ${ }^{1,2}$, Oleksandr LIASHCHUK ${ }^{1,3}$ \& Stanka ŠEBELA ${ }^{4}$
}

\begin{abstract}
UDC 551.44:621.391.81(497.471)

Igor Kachalin, Oleksandr Liashchuk \& Stanka Šebela: Periodical measurements of VLF radio signals and noise sounds in Črna Jama (Postojnska Jama)

In Črna Jama, which is part of Postojnska Jama, underground measurement of VLF (Very Low Frequency) radio signals was periodically carried out in 2012 and 2013 for detection of possible pre-seismic and/or other anomalies and to ascertain suitability of VLF monitoring in a natural cave environment. The modulation of the VLF signal was connected with a powerful atmospheric front and changes of the precipitation level. VLF data showed day and night changes and also significant changes between dry and rainy periods when water from the surface reached the cave chamber through about $30 \mathrm{~m}$ of limestone roof. During VLF monitoring we did not receive earthquake precursor signals. VLF monitoring in a karst cave could be an option for future research in understanding pre-seismic and other anomalies. On-line connection with other VLF surface or cave monitoring sites in Europe is necessary in future VLF registration. Results of preliminary VLF monitoring showed Črna Jama to be a suitable place for future studies.

Key words: VLF radio signals, noise sounds, pre-seismic anomalies, Črna Jama, Slovenia.
\end{abstract}

Izvleček

UDK 551.44:621.391.81(497.471)

Igor Kachalin, Oleksandr Liashchuk \& Stanka Šebela: Občasne meritve VLF radijskih signalov in šumov v Črni jami (Postojnska jama)

V Črni jami, ki je del Postojnske jame, smo v letih 2012 in 2013 občasno opravljali podzemne meritve VLF (zelo nizko frekvenčnih) radijskih signalov za določitev možnih predseizmičnih in/ali drugih nepravilnosti. Želeli smo določiti primernost meritev VLF v naravnem okolju kraške jame. Sprememba VLF signala je bila povezana $\mathrm{z}$ močno vremensko fronto in spremembami nivoja padavin. VLF podatki so pokazali dnevne in nočne spremembe ter izrazite spremembe med suhi$\mathrm{mi}$ in deževnimi obdobji, ko je voda s površja skozi okrog $30 \mathrm{~m}$ debel jamski strop prišla do jamske dvorane. Med merjenjem VLF nismo dobili pred-potresnega signala. VLF monitoring $\mathrm{v}$ kraški jami je lahko možnost za prihodnje raziskave razumevanja pred potresnih in drugih nepravilnosti. Povezava v realnem času z drugimi VLF površinskimi ali jamskimi merilnimi mesti v Evropi je potrebna za prihodnje VLF meritve. Rezultati predhodnih meritev VLF so pokazali, da je Črna jama primerno mesto za raziskave $\mathrm{v}$ prihodnosti.

Ključne besede: VLF radijski signali, šumi, pred-potresne nepravilnosti, Črna jama, Slovenija.

\section{INTRODUCTION}

Within the BlackSeaHazNet project (FP7 PEOPLE-2009 -IRSES-246874, Complex Research of Earthquake's Prediction Possibilities, Seismicity and Climate Change Cor- relations) geophysical observations were made in Črna Jama, which is part of Postojnska Jama, Slovenia. Underground VLF (Very Low Frequency) radio signal moni-

\footnotetext{
${ }^{1}$ National Antarctic Scientific Center (NASC), Tarasa Shevchenka blvd 16, Kiev 01601, Ukraine, e-mail: igor_kachalin@ukr.net

${ }^{2}$ AtomKomplexPrylad, 1 Magnitogorskaya st., Kiev 02660, Ukraine

${ }^{3}$ Main Center of Special Monitoring, Ukraine, e-mail: alex_liashchuk@mail.ru

${ }^{4}$ ZRC SAZU Karst Research Institute, Titov trg 2, 6230 Postojna, Slovenia, e-mail: sebela@zrc-sazu.si
}

Received/Prejeto: 09.04.2015 
toring was periodically done in 2012 and 2013 (Kachalin et al. 2013) for detection of possible pre-seismic and/or other anomalies.

Postojnska Jama is the second longest and most visited touristic cave in Slovenia. Historic geophysical researches in the cave had already started in 1932 when horizontal pendulums with photographic recording were installed. The studies were important for understanding Earth tides, underground karst hydrology and seismology (Carnera 1933). More recently, in 2004 two optical-mechanical crack gauges (TM 71) were installed in Postojnska Jama within the Dinaric oriented fault zone (NW-SE). Both instruments showed small (up to 0.08 $\mathrm{mm}$ ) micro-tectonic displacements (Gosar et al. 2009; Gosar et al. 2011; Šebela et al. 2010). The same instruments are used in numerous European caves (Briestenský et al. 2014; Stemberk et al. 2010). Two-dimensional optical measurement of the tilt of a rock mass by a static vertical pendulum in Magdalena Jama (part of Postojnska Jama) showed the existence of stress variations that are not only of local origin (high floods, local seismicity, and aseismic deformations) but can be observed very far from the origin (Kalenda et al. 2013). Temporary seismological measurements confirmed that Postojnska Jama is suitable for installation of a permanent seismic station with future real-time integration of seismological data within the Slovenian and Italian seismological networks (Živčić et al. 2014). Due to a good infrastructure (optical cable, electricity, good access from different cave entrances to outside cave infrastructure, cave train) Postojnska Jama is becoming an optimal site for different geophysical studies.

Črna Jama, which is a not very frequently visited part of Postojnska Jama, was chosen for the first periodical VLF monitoring in Slovene karst cave. Similar studies are described from other locations in Europe. Detection of electric, magnetic and seismo-acoustic signals was carried out in Amare Cave (Gran Sasso - L'Aquila, Italy). In "quiet" state only electric and magnetic signals with highest frequencies have appeared, which were connected with radio broadcastings and with lightning activity of the Earth. A "perturbed" state was connected with rainfall, atmospheric-pressure variations and thermal effects. It was recorded that micro-movements of the limestone blocks over the cave roof were invoked for production of seismo-acoustic signals (Bella et al. 1995). On 25 August 1992 an earthquake $(M=3.9)$ occurred less than $20 \mathrm{~km}$ far from Amare Cave (Gran Sasso L'Aquila, Italy) and on 4 June 1993 another earthquake ( $\mathrm{M}=4.3$ ) occurred in Umbria, $100 \mathrm{~km}$ north from Amare Cave. Before these two earthquakes electromagnetic, seismo-acoustic, and RMC (Principality of Monaco) long wave broadcasting $(216 \mathrm{kHz})$ data showed anoma- lies that can be considered earthquake precursors (Bella et al. 1996).

Through international initiative INFREP, originated in Italy, VLF/LF radio receivers are deployed in different locations in Europe. Studying the ionosphere influences on the electromagnetic waves' propagation along a certain path is a method to evidence possible modifications of ionosphere lower structure and composition as earthquake precursor. At some monitoring sites the electric component of the electromagnetic field was probably influenced by the local atmospheric conditions (Moldovan et al. 2012).

Since 2009 a network of VLF $(20-60 \mathrm{kHz})$ and LF $(150-300 \mathrm{kHz})$ radio receivers (three in Italy, one each in Austria, Greece, Portugal, Romania, Russia and Turkey) is operating in Europe to study the disturbances produced by the earthquakes on the propagation of these signals. The radio data collected during April - May 2011 were studied using the Wavelet spectra, the Principal Component Analyses and the Standard Deviation trends. Evident anomalies were revealed both in the signals broadcasted by the TRT transmitter $(180 \mathrm{kHz})$ located near Ankara and in a VLF signal coming from a transmitter located in Western Europe and collected by the receiver TUR of the network located in eastern Turkey. Evident precursor phases were pointed out (Biagi et al. 2012).

ELF (Extremely Low Frequency)-VLF emissions occurred during fracturing of rocks, in laboratory experiments, and have been recorded also before earthquakes by three ELF-VLF stations installed in Central Apennines. From August 2003 to September 2005 the signals occurred a few days before the occurrence of $M \geq 4.5$ earthquakes in the surrounding region $(100-300 \mathrm{~km})$ (Nardi et al. 2007).

Mechanical loading (opening cracks) is accompanied by the production of electromagnetic emissions (EME) and acoustic emissions (AE) in a wide frequency spectrum ranging from the $\mathrm{kHz}$ to the $\mathrm{MHz}$ bands (Contoyiannis 2015 and references therein).

Similar anomalies are not only reported during earthquakes but also during volcanic activities. On 27 October 2002 Etna (Sicily) started an eruption that was still active in January 2003. The CLT ( $\mathrm{f}=189 \mathrm{kHz}$, Sicily, Italy) radio-signal decreases appear clearly related to previous activities with some possible premonitory behaviour (Biagi et al. 2004).

Modern studies capture natural and man-made VLF radio emissions, as was the case of low Earth orbiting microsatellite DEMETER, which objective was the search for ionospheric disturbance possibly generated by pre-seismic activity and study of space weather and ionospheric phenomena (Parrot et al. 2015). 
Short-term earthquake precursors are generally non-seismic and equipment developed for seismology is not designed to detect them. Observations of precursors have not yet been perfect enough and some fundamental aspects of non-seismic precursors are still unresolved (Uyeda et al. 2009).
The aim of the underground VLF monitoring in Črna Jama was to detect VLF radio signals and noise sounds, to determine possible pre-seismic and/or other anomalies, and to ascertain suitability of VLF monitoring in a natural karst cave.

\section{METHODOLOGY AND SITE DESCRIPTION}

In the period of 6-7 September and 14-20 September 2012, Črna Jama (Fig. 1) provided the pilot experiment site of the underground registration of the radio emission of VLF transmitters. Simple experimental equipment was used for registration of the radio signals in the band of 3-20 kHz:

- computer for digitizing and "in-situ" data processing

- miniature VLF receiver/amplifier

- around $140 \mathrm{~m}$ of linear antenna.

The complex instrumentation was installed on the bottom of the cave (Fig. 1). At the period of installation and tuning of the instrumentation few places for long length antenna were tested. The main requirements for the installation included:

- minimal electromagnetic noise
- power supply $220 \mathrm{~V}$

- no (or very low) human presence.

The first place for antenna installation in 2012 was in the artificial tunnel at the southern part of the cave. Testing of the recording data showed high electric noise coming from underground high voltage cable in the tunnel. This first location of the antenna cable was therefore changed to another. The second location of the antenna cable was around the central part of the cave (Fig. 1).

In 2013 the installation of the experimental VLF equipment in Črna Jama for continuous receiving of the radio transmitter signals in the VLF band was done from 27 September to 11 October 2013. Before field installation the VLF receiver was tested in an office at Karst Research Institute ZRC SAZU Postojna, Slovenia (Fig. 2).

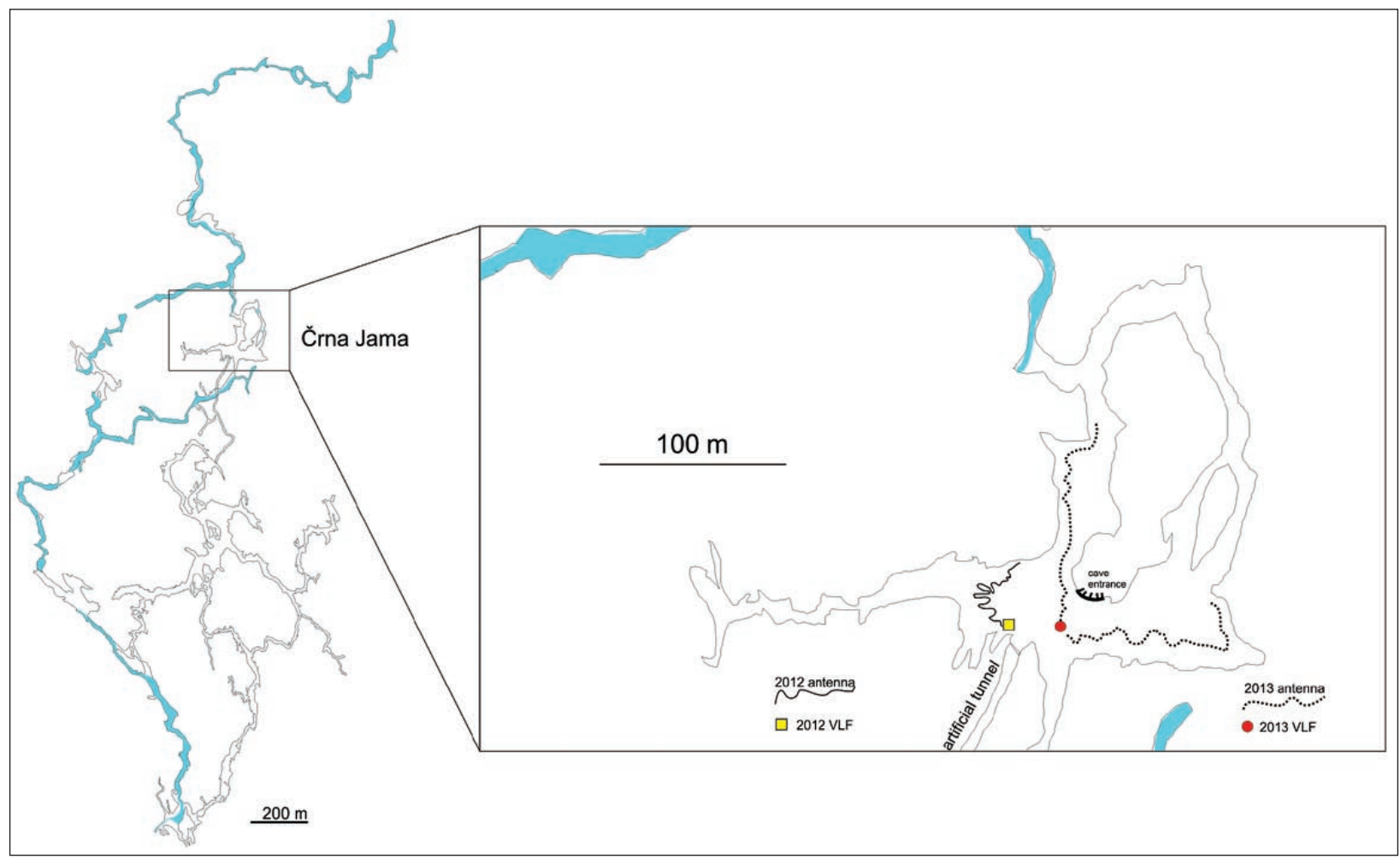

Fig. 1: Črna Jama and VLF monitoring experimental sites in 2012 and 2013. 


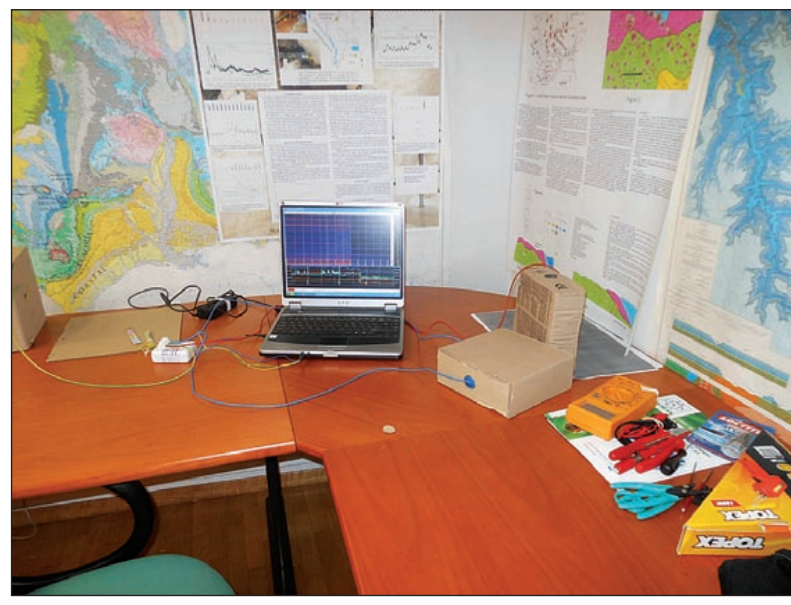

Fig. 2: Testing of the VLF receiver in office before installation in the cave (Photo: S. Šebela).

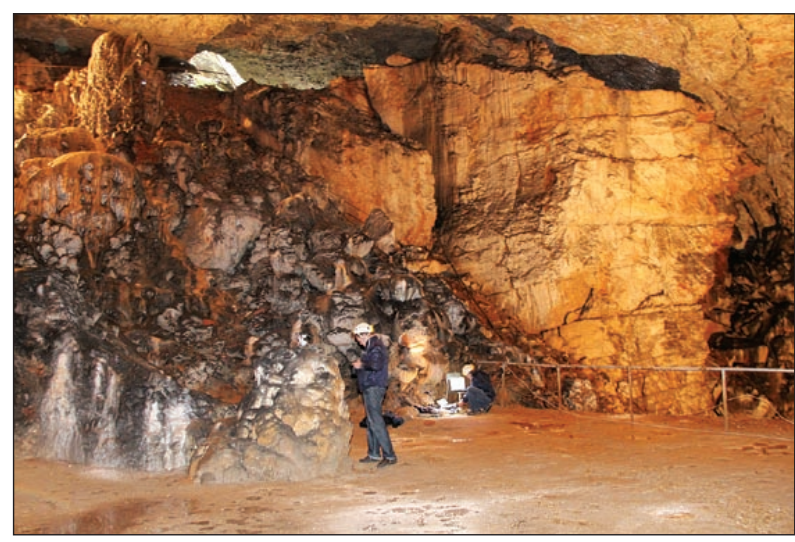

Fig. 3: Installation of the VLF equipment in 2013 with Črna Jama cave entrance in the back (Photo: S. Šebela).

In 2013 two cable antennas were installed in Črna Jama (Figs. 1 and 3). Each was $100 \mathrm{~m}$ long. One was in general direction $\mathrm{E}-\mathrm{W}$ and another in $\mathrm{N}-\mathrm{S}$. The one in $\mathrm{N}-\mathrm{S}$ direction did not give good data because a high voltage electric cable was running nearby. In our first plans

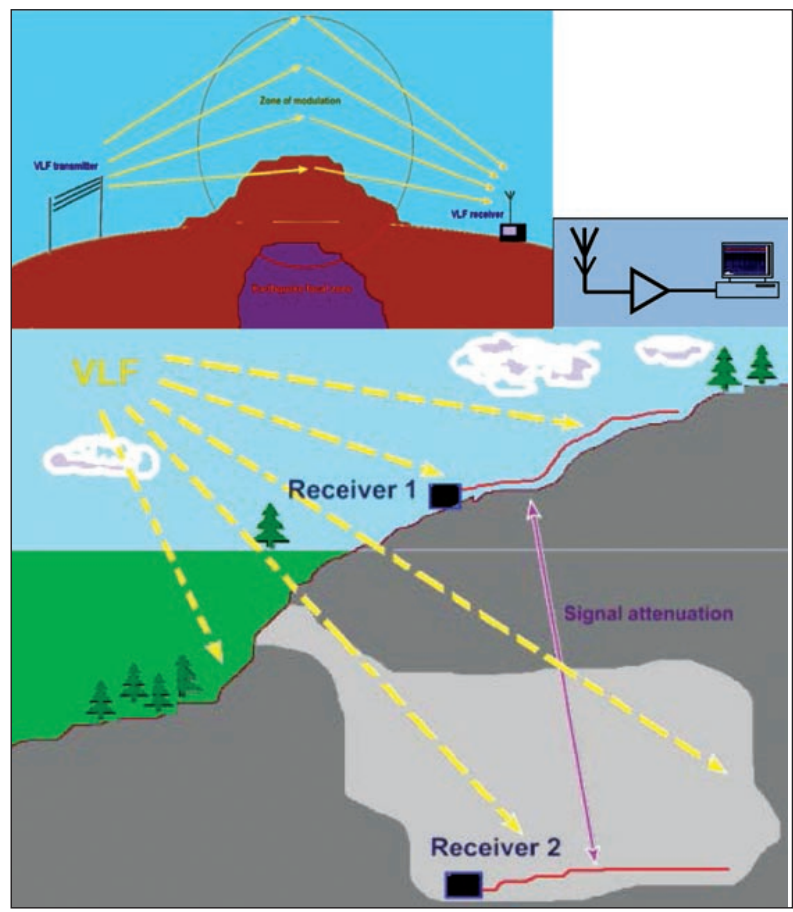

Fig. 4: Intended configuration of VLF monitoring in Črna Jama, which was not fully accomplished.

we wanted to put one receiver in the cave and another on the surface above the cave (Fig. 4). We also wanted to put one antenna in the cave and the other on the surface. But because we did not get official permission for installation in the forest on the surface it was not possible to do this.

The principal scientific contribution of the investigation was the use of non-traditional techniques - underground VLF measurements for studying and analysing the possibility of using the passive method of registering of the variations of the power of carrier frequencies from VLF transmitters in the caves at an underground receiver as possible pre-seismic anomalies.

\section{RESULTS AND DISCUSSION}

During two short period installations of the experimental equipment in 2012 the results (Figs. 5 and 6) showed "modulation" of the VLF signal connected with powerful atmospheric front and change of the precipitation level (Fig. 7).

In 2013 a nearly one month long continuous underground VLF registration in Črna Jama (Figs. 8 and 9) showed similar conditions as in 2012. VLF signal "mod- ulation" was connected with changes in meteorological conditions.

The preliminary measurements of the experimental underground recording of VLF signals gave promising results. We propose the use of VLF (with ELF and LF in the future) passive observations in combination with traditional geophysical technologies for monitoring cave conditions and registration of possible pre-seismic anomalies. 


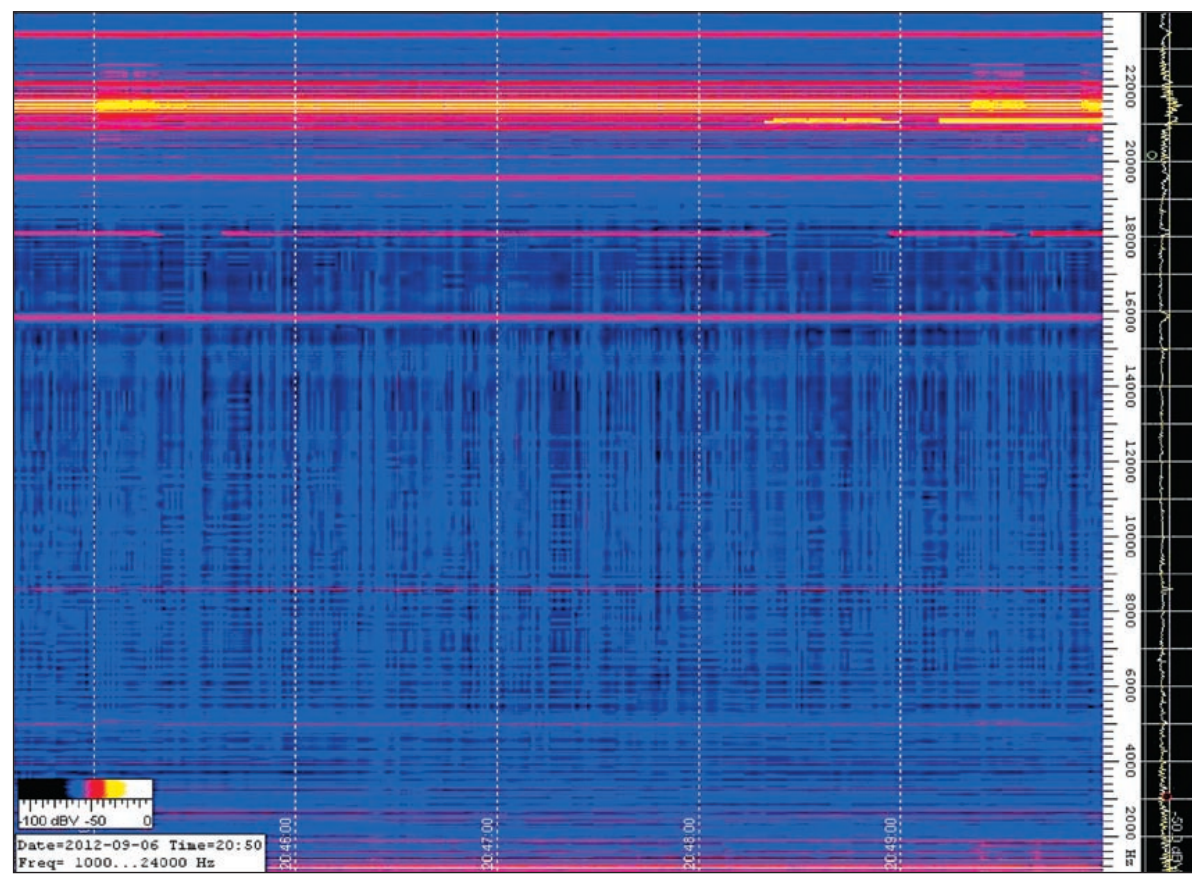

Fig. 5: Waterfall spectra of the receiving broad band signal at Črna Jama on 6 September 2012

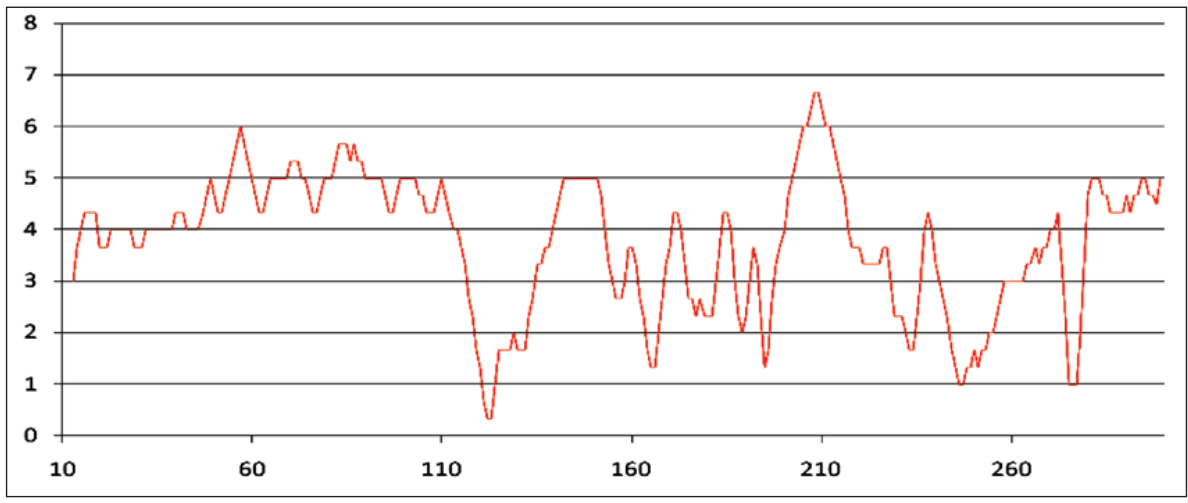

Fig. 6: One day (24 hours) amplitude variation in 2012 of the observed frequency $15.9 \mathrm{kHz}$. Vertical relative numbers are about $10 \mathrm{db}$.

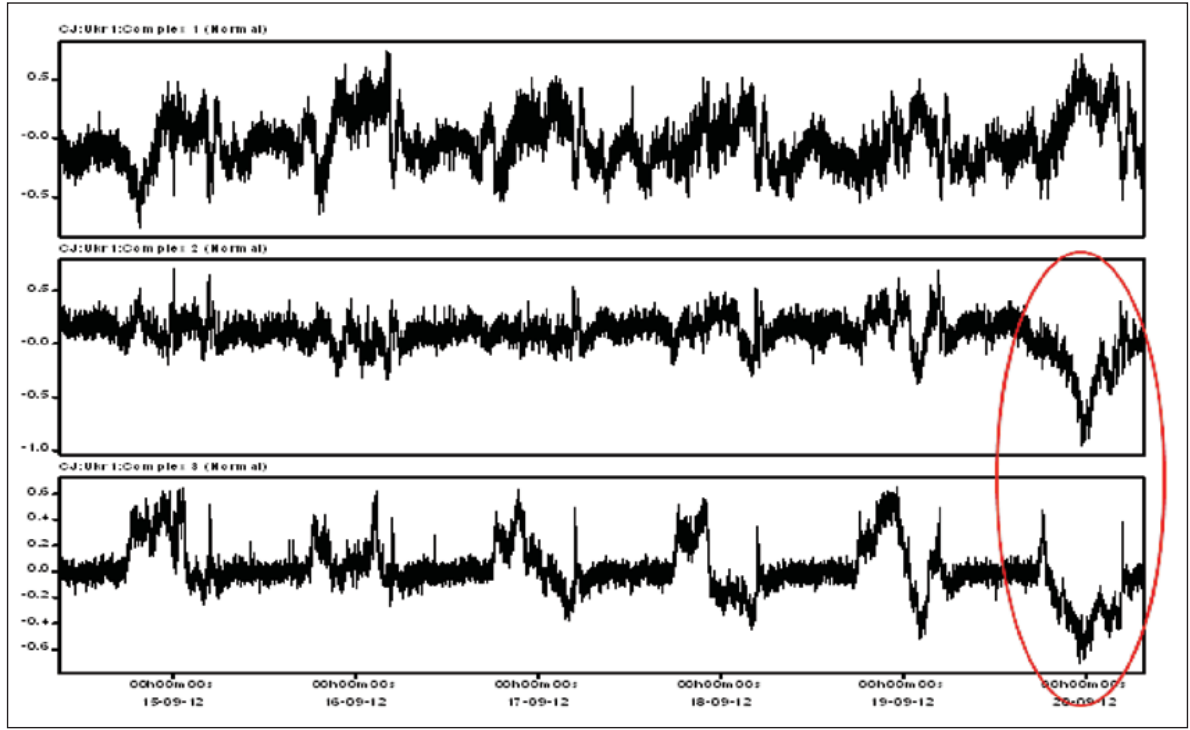

Fig. 7: Processed VLF data (14-20 September 2012). In the ellipse is shown "modulation" of the VLF signal connected with a powerful atmospheric front and change of the precipitation rate. 

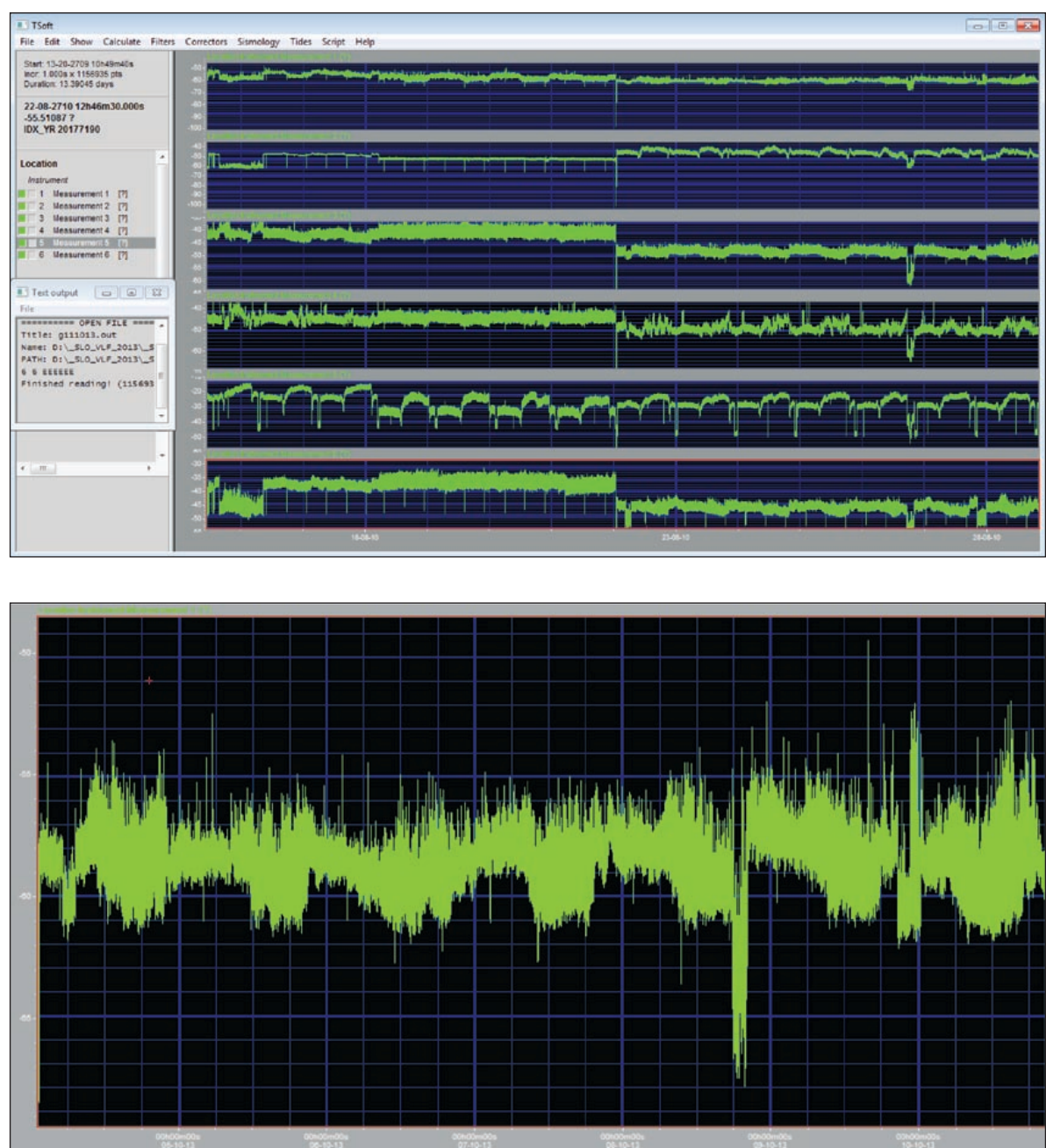

Fig. 8: VLF data from Črna Jama processed and analysed for the period 27 September to 11 October 2013 .

Fig. 9: VLF data from Črna Jama in the period 4-11 October 2013 with "modulation" of the VLF signal.
Processed data and complex analyses of the raw data collected by the experimental VLF equipment in Črna Jama, are together with meteorological, seismic and INTERMAGNET (http://www.intermagnet.org) data, suitable for definition of the working regime of the equipment and for detection of possible earthquake precursor signals.

\section{CONCLUSIONS}

In 2012 VLF monitoring covered a period of one day and another period of one week; and in 2013 we made nearly one month of continuous underground recording in Črna Jama. The experimental underground registration of the VLF radio transmitter is a validated possibility that can be used in future observations. VLF data showed day and night changes and also significant changes between dry and rainy periods when water from the surface reached the cave chamber through about $30 \mathrm{~m}$ of limestone roof.
Regular noise probably related to unknown radar signals was detected. During VLF monitoring we did not receive an earthquake precursor signal. VLF monitoring in karst cave is a promising option for future researches in understanding pre-seismic anomalies but it has to be continuous for more years with registration in real time. On-line connection with other VLF surface or cave monitoring sites in Europe is necessary in future VLF registration. 


\section{ACKNOWLEDGEMENTS}

The visit of Ukrainian colleagues to Slovenia was realized within the BlackSeaHazNet project (FP7 PEOPLE-2009IRSES-246874, Complex Research of Earthquake's Prediction Possibilities, Seismicity and Climate Change Correlations). The permission for VLF monitoring in Črna
Jama was obtained from Agencija RS za okolje (Agency of the Republic of Slovenia for Environment) and Postojnska jama d.d. We are thankful to Dr. Trevor R. Shaw for revising the English.

\section{REFERENCES}

Bella, F., Biagi, P.F., Caputo, M., Della Monica, G., Ermini, A., Plastino, W., Sgrigna, V. \& D. Zilpimiani, 1995: Electromagnetic and seismoacoustic signals revealed in karst caves (Central Italy).- Il Nuovo Cimento C, 18, 1, 19-32. DOI: http://dx.doi. org/10.1007/BF02561456

Bella, F., Biagi, P.F., Caputo, M., Della Monica, G., Ermini, A., Plastino, W. \& V. Sgrigna, 1996: Normal and anomalous behaviour of electric, magnetic and seismoacoustic signals recorded in the Amare cave.Annali di Geofisica, 39, 1, 97-100.

Biagi, P.F., Piccolo, R., Castellana, L., Ermini, A., Martellucci, S., Bellecci, C., Capozzi, V., Perna, G., Molchanov, O. \& M. Hayakawa, 2004: Variations in a LF radio signal on the occasion of the recent seismic and volcanic activity in Southern Italy.- Physics and Chemistry of the Earth, 29, 4-9, 551-557. DOI: http://dx.doi.org/10.1016/j.pce.2003.10.005

Biagi, P.F., Righetti, F., Maggipinto, T., Schiavulli, L., Ligonzo, T., Ermini, A., Moldovan, I.A., Moldovan, A.S., Gonçalves Silva, H., Bezzeghoud, M., Contadakis, M.E., Arabelos, D.N., Xenos, T.D. \& A. Buyuksarac, 2012: Anomalies Observed in VLF and LF Radio Signals on the Occasion of the Western Turkey Earthquake $\left(\mathrm{M}_{\mathrm{w}}=5.7\right)$ on May 19, 2011.International Journal of Geosciences, 3, 856-865. DOI: http://dx.doi.org/10.4236/ijg.2012.324086

Briestenský, M., Stemberk, J. \& M.D. Rowberry, 2014: The use of the damaged speleothems and in situ fault displacement monitoring to characterise active tectonic structures: an example from Západní Cave, Czech Republic.- Acta Carsologica, 43, 1, 129-138. DOI: http://dx.doi.org/10.3986/ac.v43i1.626

Carnera, L., 1933: La stazione dei pendoli orizzontali nelle R.R. Grotte di Postumia.- Bollettino di Geodesia e Geofisica, 9-10, XII, 1-13.
Contoyiannis, Y., Potirakis, S.M., Eftaxias, K. \& L. Contoyianni, 2015: Tricritical crossover in earthquake preparation by analyzing preseismic electromagnetic emissions.- Journal of geodynamics, 84, 40-54. DOI: http://dx.doi.org/10.1016/j.jog.2014.09.015

Gosar, A., Šebela, S., Košt’ák, B. \& J. Stemberk, 2009: Surface versus underground measurements of active tectonic displacements detected with TM 71 extensometers in western Slovenia.- Acta Carsologica, 38, 2-3, 213-226. DOI: http://dx.doi.org/10.3986/ ac.v38i2-3.123

Gosar, A., Šebela, S., Košt’ák, B. \& J. Stemberk, 2011: On the state of the TM 71 extensometer monitoring in Slovenia: Seven years of micro-tectonic displacement measurements.- Acta Geodyn. Geomater., 8, 4, 389-402.

Kachalin, I., Liashchuk, O., Šebela, S. \& J. Vaupotič, 2013: Underground geophysical observations in caves.- In: Mavrodiev, S. (ed.) Complex research of earthquake's forecasting possibilities, seismicity and climate change correlations, Proceedings of the BlackSeaHazNet Conclusion Workshop, $16^{\text {th }}-20^{\text {th }}$ December 2013, Sofia. INRNE, BAS, 116-121, Sofia.

Kalenda, P., Neumann, L. \& S. Šebela, 2013: Early results of micro-deformation measurements in Magdalena Jama (Slovenia) by a vertical static pendulum.- Acta Carsologica, 42, 1, 143-154. DOI: http://dx.doi. org/10.3986/ac.v42i1.635

Moldovan, I.A., Moldovan, A., Biaggi, P.F., Placinta, A.O. \& T. Maggipinto, 2012: The INFREP European VLF/LF radio monitoring network - present status and preliminary results of the Romanian monitoring system.- Romanian Reports in Physics, 64, 1, 263-274.

Nardi, A., Caputo, M. \& C. Chiarabba, 2007: Possible electromagnetic earthquake precursors in two years of ELF-VLF monitoring in the atmosphere.- Bollettino di Geofisica Teorica ed Applicata, 48, 2, 205 212. 
Parrot, M., Berthelier, J.J., Blecki, J., Brochot, J.Y., Hobora, Y., Lagoutte, D., Lebreton, J.P., Němec, F., Onishi, T., Pinçon, J.L., Píša, D., Santolík, O., Sauvaud, J.A. \& E. Slominska, 2015: Unexpected Very Low Frequency (VLF) Radio Events Recorded by the Ionospheric Satellite DEMETER.- Surv. Geophys., 36, 3, 483-511. DOI: http://dx.doi.org/10.1007/s10712015-9315-5

Stemberk, J., Košták, B. \& S. Cacoń, 2010: A tectonic pressure pulse and increased geodynamic activity recorded from the long-term monitoring of faults in Europe.- Tectonophysics, 487, 1-12. DOI: http:// dx.doi.org/10.1016/j.tecto.2010.03.001

Šebela, S., Vaupotič, J., Košták, B. \& J. Stemberk, 2010: Direct measurement of present-day tectonic movement and associated radon flux in Postojna cave, Slovenia.- Journal of Cave and Karst Studies, 72, 1, 21-34. DOI: http://dx.doi.org/10.4311/ jcks2009es0077
Uyeda, S., Nagao, T. \& M. Kamogawa, 2009: Short-term earthquake prediction: Current status of seismoelectromagnetics.- Tectonophysics, 470, 205-213. DOI: http://dx.doi.org/10.1016/j.tecto.2008.07.019

Živčić, M., Costa, G., Suhadolc, P. \& S. Šebela, 2014: Temporary seismological measurements in the Postojna Cave System.- Acta Carsologica, 43, 1, 149157. DOI: http://dx.doi.org/10.3986/ac.v43i1.569 